\title{
Experimentation of Grapevine Cultivation in Organic System, on Five Different Romanian Vineyards
}

\author{
Aurora RANCA ${ }^{1 *}$, Victoria ARTEM ${ }^{1}$, Ionica DINA ${ }^{1}$, Liliana PARCALABU ${ }^{2}$, \\ Maria ILIESCU ${ }^{3}$, Gabriel TABARANU ${ }^{3}$, Ancuta NECHITA ${ }^{4}$ \\ ${ }^{1}$ Research Station for Viticulture and Oenology Murfatlar, Romania, \\ ${ }^{2}$ Research Institute for Viticulture and Oenology Valea Calugareasca, Romania, \\ ${ }^{3}$ Research Station for Viticulture and Oenology Blaj, Romania, \\ ${ }^{4}$ Research Station for Viticulture and Oenology Bujoru, Romania \\ ${ }^{5}$ Research Station for Viticulture and Oenology Iasi, Romania \\ *)Corresponding author, e-mail: auroraranca@yahoo.com
}

BulletinUASVM Horticulture 73(2) / 2016

Print ISSN 1843-5254, Electronic ISSN 1843-5394

DOI:10.15835/buasvmcn-hort:12206

\begin{abstract}
In five Romanian vineyards, in 2013-2014 period was experimented organic system growing on grape varieties for wine representative for five different area, here were applied organic growing technology in parallel with the conventional one (control). The white varieties studied were: Chardonnay (Murfatlar and Dealu Mare), Sauvignon blanc and Muscat Ottonel (Tarnave), Feteasca regala (Tarnave, Bujoru and Copou-Iasi). Red varieties are Cabernet Sauvignon (Murfatlar and Dealu Mare) and Merlot (Bujoru).

Concerning evolution of main climatic factors for the years 2013-2014 it is show that the annual average air temperature increase compared with the average of the years 1991-2010; it is observed an increasing in mean annual temperature, mean temperature during the growing season and the sum of sunshine hours. The water regime was kept constant, registering values close to the annual average, both during the growing season and at entire year.

The weeds spectrum was represented both by dicotyledonous as knotweed (Polygonum aviculare), Veronica (Stellaria media), news (Amaranthus retroflexus), bindweed (Convolvurus arvensis) and monocotyledonous as grass thick (Cynodon dactylon).

Concerning the phytosanitary status, at Murfatlar were registered problems with oidium attack, with all main disease at Dealu Mare and with downy mildew at Bujoru. In all vineyards the next pests has been found: grape mouth (Lobesia botrana) and spiders (Tetranichus sp.). Schemes of treatments focused generally on substances based on copper and sulfur to combat diseases and for pests have been used pheromonal traps or other certified organic products.

The grapes harvest was lower in organic plots with till $25 \%$ but their quality parameters were almost equally in both growing variants.
\end{abstract}

Keywords: adaptability, disease control, ecoclimatic conditions, organic system, pest control, weeds

\section{INTRODUCTION}

Organic viticulture is an alternative mode of production based on rational exploitation of nature (Ranca and Toncea, 2011).

The principles of organic viticulture are based on maximum use of local resources, in parallel to minimizing the economic and environmental risks (Bernaz, Dejeu, 1999). It aims mainly: maintaining the biodiversity, preserving the biological activity of the soil, preventive crop protection and obtaining quality productions.

The first data on organic cultivation in vineyards appear in the ' $50 \mathrm{~s}$, when pioneers 
in Switzerland and Germany applied the basic principles of organic farming for viticulture.

Currently, EU cultivates $84 \%$ from total surface with organic vineyards. The biggest producers are Spain, Italy and France (The world of organic agriculture, 2015).

In Romania organic farming has one of the greatest opportunities due to the following features: the soil is largely "rested" without excessive mechanical works, in many regions is relatively "clean" (gaininganimportant competitive advantage equivalent with the conversion period which is needed to remove chemical residue and fertilizers compared to other areas in Europe), the demand for the organic products is increasing both on internal market as well as for the export.

The total sales of organic products in Romania rise to about 10 million euros, which represents less than $1 \%$ of the retail market, very low compared to $3-5 \%$, as is the European average (infomina.ro, 2008).

The paper aims to test the suitability to adopt ecological culture system in five Romanian representative vineyards.

\section{MATERIALS AND METHODS}

In the growing centers Murfatlar, Dealu Mare, Târnave, Bujoru and Copou-Iasi, in 2013-2014 were set up five experimental plots with grape varieties for wine representative for each area, and here were applied organic growing technology in parallel with the conventional one (control). The white varieties studied were: Chardonnay (Murfatlar and Dealu Mare), Sauvignon blanc and Muscat Ottonel (Tarnave), Feteasca regala (Tarnave, Bujoru and Copou-Iasi). Red varieties were Cabernet Sauvignon (Murfatlar and Dealu Mare) and Merlot (Bujoru). Trellis system is halfhigh with stalk of 60-70 cm height, except on Tarnave, there where culture system is with short stalk. The average density of plants per hectare was 3877 at Bujoru and Copou-Iasi, 4166 at Murfatlar and Tarnave and 5000 plants in Dealu Mare. The plant was grafted on the Berlandieri x Riparia rootstocks: Kober 5BB at Dealu Mare and Copou -Iasi and Selection Oppenheim 4-4 in Murfatlar and Bujoru.

In Târnave and Bujoru areas the vineyards are protected in dormant period. System maintenance of the soil is plowed between rows and un- fertilized, except Murfatlar there where fertilizer based on seaweed was applied.

Were applied two growing systems, organic (no fertilizers, no herbicides, phytosanitary treatments accepted) and conventional.

Are presented data on key climate indicators, the weed spectrum and infestation degree with pathogens: at diseases was calculated degree of attack, GA\%=FxI/100, where " $F$ " is attack frequency and "I" is intensity of attack given in notes from 0 to 6 , and at the pests was used method of capture using pheromonal traps: atraBot). Treatment plant scheme was adapted to wine regions. In each vineyards was applied a phytosanitary control scheme in accordance with Reg. EC 834/2007 and Reg. EC 889/2008 (madr. ro).

The obtained harvests were analyzed from quantitative and quality point of view. Statistical analysis of data was done using SPSS Statistics 17.0, using $\mathrm{t}$ - test and Pearson correlation coefficients.

\section{RESULTS AND DISCUSSIONS}

Soil types encountered in the five wine centers are: chernozem-limestone (Murfatlar) red preluvisoil typical and molic (Dealu Mare), sandyclay (Tarnave), chernozem (Bujoru) and cambic (Copou-Iaşi). All these are favorable for grapevine culture. Most soils have good humus content, $1.5-2 \%$ and are medium to well supplied with nutrients.

From the analysis on climatic indexes for the years 2013-2014 it is show that the annual average air temperature increase compared with the average of the years 1991-2010; is observed an increasing in mean annual temperature, mean temperature during the growing season and the value of sum of sunshine hours. The water regime was kept constant, registering values close to the annual average, both during the growing season and at entire year.

The values of hydro-thermal coefficient - $\mathrm{CH}$ of 2013 year are higher than the average, heliothermal index - Ihr values are within normal levels, except Murfatlar where thermal resources exceded. The bioclimatic index - Ibcv (Constantinescu et all., 1964) is within normal limits, noting, however, at Murfatlar, a rising trend of water resources in detriment of heliothermal. The ability of oenoclimat index - IAOe (Teodorescu 1987) indicating favorable conditions for producing both 
Tab. 1. Mains climatic indicators registered in the period 2013-2014, compared to the multiannual average (1990-2010)

\begin{tabular}{ccccccc}
\hline Vineyard & Years & CH & Ihr & Ibcv & IAOe & Iar-DM \\
\hline \multirow{3}{*}{ Murfatlar } & $1991-2010$ & 0,85 & 3,5 & 13,6 & 5093,0 & 22,9 \\
\cline { 2 - 7 } & 2013 & 1,2 & 4,4 & 7,2 & 5549,2 & 25,8 \\
\cline { 2 - 7 } Dealu Mare & 2014 & 1,1 & 3,4 & 6,4 & 5214,0 & 30,5 \\
\cline { 2 - 7 } & $1991-2010$ & 1,8 & 2,6 & 7,2 & 4869,0 & 29,3 \\
\cline { 2 - 7 } & 2013 & 1,9 & 3,0 & 10,4 & 5159,5 & 28,8 \\
\hline \multirow{3}{*}{ Târnave } & 2014 & 1,55 & 2,39 & 6,13 & 4566,0 & 38,4 \\
\cline { 2 - 7 } & $1991-2010$ & 1,34 & 1,86 & 5,74 & 3876,0 & 30,7 \\
\hline \multirow{3}{*}{ Bujoru } & 2013 & 1,36 & 2,00 & 5,50 & 3856,5 & 29,2 \\
\cline { 2 - 7 } & 2014 & 1,35 & 1,93 & 5,65 & 4171,0 & 24,6 \\
\hline & $1991-2010$ & 0,82 & 2,36 & 8,47 & 4839,0 & 20,5 \\
\hline \multirow{3}{*}{ Copou-Iaşi } & 2013 & 1,58 & 2,36 & 5,58 & 4527,9 & 34,2 \\
\cline { 2 - 7 } & 2014 & 0,8 & 2,03 & 10,2 & 4549,3 & 21,6 \\
\cline { 2 - 7 } & $1991-2010$ & 1,3 & 2,1 & 7,1 & 4415,1 & 30,3 \\
\hline
\end{tabular}

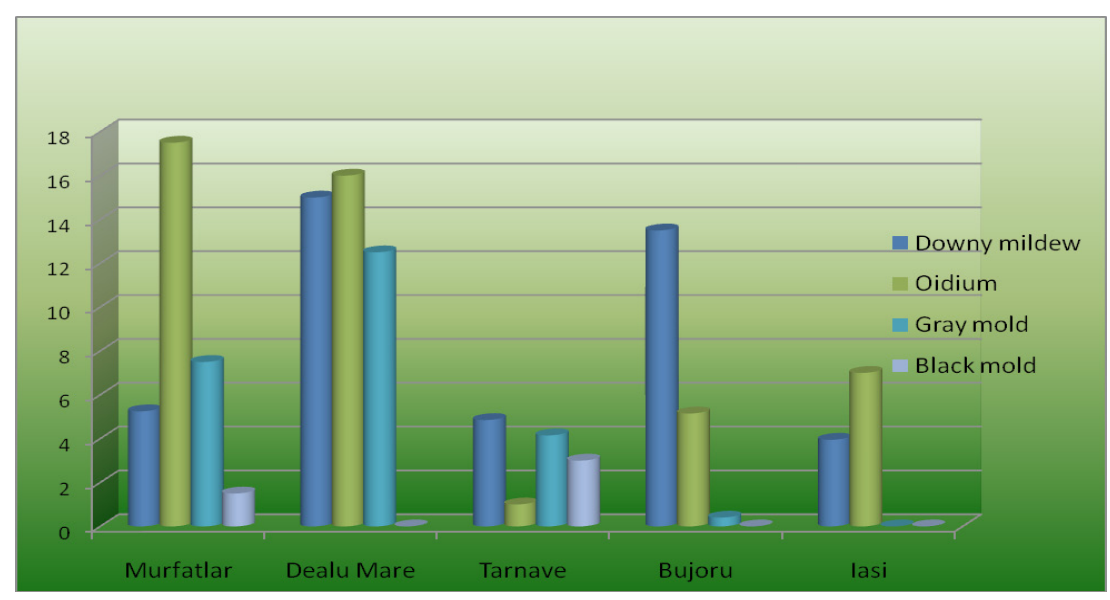

Fig. 1. The phytosanitary status of experimenthal plots - degree of attack (average data 2013-2014)

red and white wines - over 4300 values. Martonne aridity index values - Iar-DM show a moderate climate humidity in all five vineyards (table 1 ).

The spectrum of weed infestation in the experimental plots: supervision of weed development aimed both identifying new hosts with epidemiological significance and the overall assessment of the degree of weed in the plots (determined using metric frame).

The weeds structure found in Murfatlar vineyard: dominance between monocots of couch grass creeping (Agropyrum repens) and couch grass thick (Cynodon dactylon) and between dicots: bindweed (Convolvurus arvensis) - degree of infestation 28\%, shepherd's purse (Capsela bursa pastoris) and news (Amaranthus retroflexus) - $12 \%$ degree of infestation.

In the Dealu Mare vineyard, it is observed the dominance of annual dicotyledonous as knotweed (Polygonum aviculare) - 32\% degree of infestation, shepherd's purse (Capsella bursa pastoris) and Veronica (Stellaria media) - 23\% degree of infestation.

In the vineyard Târnave are founded dominance of couch grass thick (Cynodon dactylon) between monocots and from dicots bindweed (Convolvulus arvensis) - degree ifestare 15\%, dandelion (Taraxacum officinale), 
Tab. 2. Treatment scheme used in the experimental plots, Murfatlar 2014

\begin{tabular}{|c|c|c|c|c|}
\hline $\begin{array}{l}\text { Phenologic phasis } \\
\text { development } \\
\text { Approximate date }\end{array}$ & $\begin{array}{c}\text { Disease, pest or weed } \\
\text { treated }\end{array}$ & $\begin{array}{l}\text { Product or mixture used } \\
\text { (active substance) }\end{array}$ & $\begin{array}{l}\text { Dose used } \\
\text { (pc. , kg or l/ } \\
\text { ha) }\end{array}$ & Observations \\
\hline $\begin{array}{l}\text { Buds oppening - } 20- \\
30 \text { april }\end{array}$ & Grapes moth & $\begin{array}{l}\text { Pheromonal traps } \\
\text { atraBot }\end{array}$ & 3 & Installing the traps \\
\hline \multirow{3}{*}{$\begin{array}{c}\text { Shoots of } 20-25 \mathrm{~cm} \\
\text { lenght } \\
15-25 \text { May }\end{array}$} & Downy mildew & Copper hydroxide $53,8 \%$ & 2 & \multirow{3}{*}{$\begin{array}{l}\text { Spray program based on } \\
\text { accurate forecasting of pests } \\
\text { and diseases. }\end{array}$} \\
\hline & Powdery mildew & Sulphure $80 \%$ & 3 & \\
\hline & Foliar fertilizer & $\begin{array}{l}\text { Concented solution derived } \\
\text { from seaweed and } \\
\text { potassium hydroxide }\end{array}$ & 1 & \\
\hline \multirow{3}{*}{$\begin{array}{l}\text { Before flowering 20- } \\
\text { 30 May }\end{array}$} & Downy mildew & Copper hydroxide $53,8 \%$ & 1,5 & \multirow{2}{*}{ Safety treatment } \\
\hline & $\begin{array}{l}\text { Powdery mildew } \\
\text { Gray Mold }\end{array}$ & Mimosa extract $80 \%$. & 2 & \\
\hline & Foliar fertilizer & $\begin{array}{l}\text { Concented solution derived } \\
\text { from seaweed and } \\
\text { potassium hydroxide }\end{array}$ & 1 & \\
\hline \multirow{2}{*}{$\begin{array}{l}\text { End of flowering } \\
10 \text { June }\end{array}$} & Downy mildew & Copper hydroxide $77 \%$ & 2 & \multirow{2}{*}{$\begin{array}{l}\text { The treatments are done } \\
\text { at the alert moment, } \\
\text { depending on whether } \\
\text { attacks }\end{array}$} \\
\hline & Powdery mildew & $\begin{array}{l}\text { Micronized wettable sulfur } \\
80 \%\end{array}$ & 3 & \\
\hline \multirow{3}{*}{$\begin{array}{l}\text { Grain increasing } \\
\text { 20-30 June }\end{array}$} & $\begin{array}{l}\text { Grapes moth G2, } \\
\text { changing the traps }\end{array}$ & $\begin{array}{l}\text { Pheromonal traps } \\
\text { atraBot }\end{array}$ & 3 & \multirow{3}{*}{$\begin{array}{l}\text { The treatments are done } \\
\text { at the alert moment, } \\
\text { depending on whether } \\
\text { attacks }\end{array}$} \\
\hline & Downy mildew & Copper hydroxide 53,8\% & 2 & \\
\hline & Powdery mildew & Sulphure $80 \%$ & 3 & \\
\hline \multirow{3}{*}{$\begin{array}{l}\text { Compacting brunches } \\
\text { July }\end{array}$} & Downy mildew & $\begin{array}{l}\text { Solution in water of Chitosan } \\
\text { (poly - D - glucosamine) } 4 \% .\end{array}$ & 3 & \multirow{3}{*}{$\begin{array}{l}\text { The treatments are done } \\
\text { at the alert moment, } \\
\text { depending on whether } \\
\text { attacks }\end{array}$} \\
\hline & Powdery mildew & $\begin{array}{l}\text { Micronized wettable sulfur } \\
80 \% \\
\end{array}$ & 3 & \\
\hline & Foliar fertilizer & $\begin{array}{c}\text { Concented solution derived } \\
\text { from seaweed and } \\
\text { potassium hydroxide }\end{array}$ & 1 & \\
\hline \multirow{3}{*}{$\begin{array}{l}\text { Beginning of } \\
\text { rippening } \\
20-30 \text { July }\end{array}$} & $\begin{array}{l}\text { Grapes moth G3, } \\
\text { changing the traps }\end{array}$ & $\begin{array}{c}\text { Laser } 240 \mathrm{Sc} \text { - biological } \\
\text { insecticide (active ingredient: } \\
\text { spinosad) }\end{array}$ & 3 & \multirow{3}{*}{$\begin{array}{l}\text { Partial defoliation in the } \\
\text { grapes area. } \\
\text { The treatments are done } \\
\text { at the alert moment, } \\
\text { depending on whether } \\
\text { attacks }\end{array}$} \\
\hline & Downy mildew & Copper hydroxide $77 \%$ & 2 & \\
\hline & Powdery mildew & $\begin{array}{l}\text { Micronized wettable sulfur } \\
80 \%\end{array}$ & 5 & \\
\hline $\begin{array}{l}\text { Rippening } \\
1-10 \text { August }\end{array}$ & Downy mildew & Copper hydroxide $77 \%$ & 2 & \multirow{2}{*}{$\begin{array}{l}\text { The treatments are done } \\
\text { at the alert moment, } \\
\text { depending on whether } \\
\text { attacks }\end{array}$} \\
\hline 10-20 August & $\begin{array}{l}\text { Powdery mildew } \\
\text { Gray Mold }\end{array}$ & Mimosa extract $80 \%$. & 3 & \\
\hline
\end{tabular}




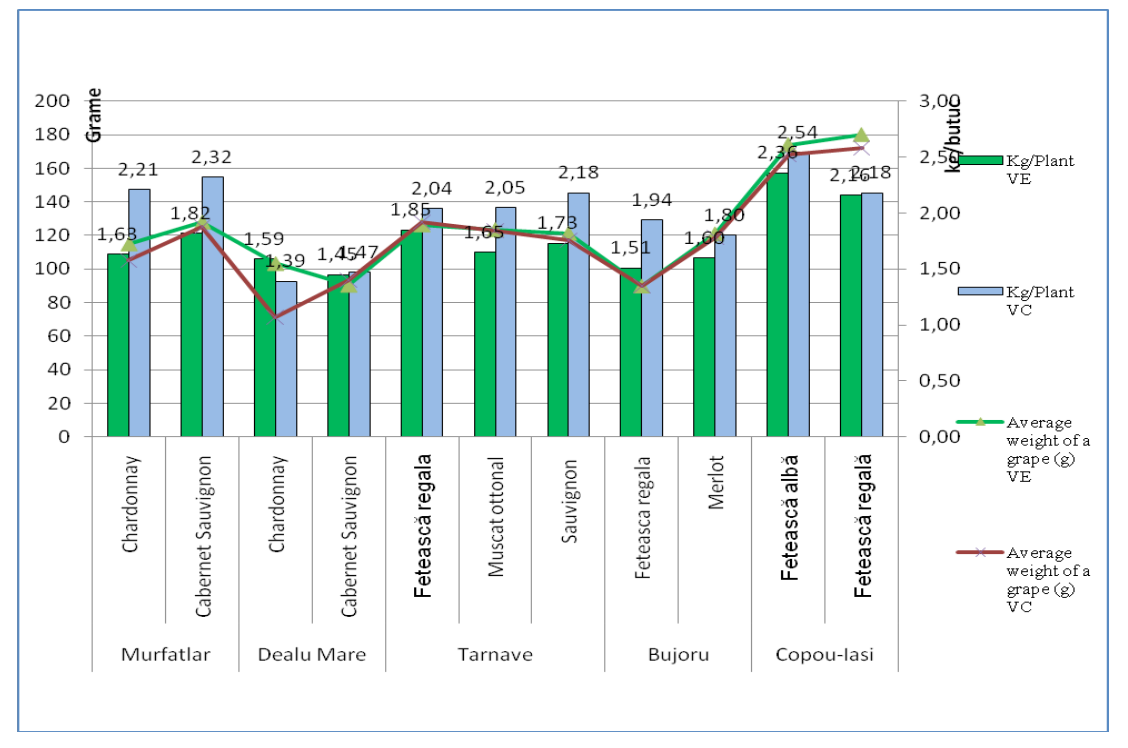

Fig. 2. Grape production obtained in Organic plots (VE: ecological variants) and control (VC: conventional variants) - average data 2013-2014

news (Amaranthus retroflexus), wild spinach (Chenopodium album) - 10\% degree of infestation and shepherd's purse (Capsela bursa pastoris).

In Bujoru vineyard was found mainly thick couch grass (Cynodon dactylon) from monocots - 25\% degree of infestation and dandelions (Taraxacum officinale) - 15\% degree of infestation, from diocots.

In Copou-Iasi prevails news (Amaranthus retroflexus) - $14 \%$ degree of infestation and shepherd's purse (Capsela bursa pastoris).

Plant protection: During the experimental years 2013-2014, in the experimental plots the studied grape-vine varieties showed medium resistance to downy mildew (Plasmopara viticola), powdery mildew (Uncinula necator), gray mold (Botrytis cinerea) and black mold (Guignardia bidwellii)(figure 1) .

In all areas the pest has been found are: grape mouth (Lobesia botrana) and mites (Tetranichus sp.) The highest density was recorded at grape mouth in all experimental plots, but the economic threshold of damage - 100 butterflies/trap/ week was not reached, the varieties showing good resistance at this pest. In case of mites, was found: Tetranychus urticae, Calepitrimerus vitis, Panonychus ulmi and Eriophyes vitis. Their density has not exceeded the economic damage threshold.

Regarding works done in plantations, they complied with the rules imposed by the ecological system (Reg. EC 834 in 2007): weeds management was performed manually or mechanically, the focus was on managing foliar surface in order to balancing the relationship between the quantity of grapes and leaves (sterile shoots removed, conducting shoots between the wire, shorting, defoliating, reducing bunches).

Schemes of treatments focused generally on substances bassed on copper and sulfur to combat diseases and for pests have been used pheromonal traps (for male mass trapping) or other certified organic products (Table 2 ).

The quantity of metallic copper was under 6 $\mathrm{kg} / \mathrm{ha}$, the limit admitted by Reg. EC 889/2008.

Depending on the degree of attack, treatments schemes included 6 to 9 treatments. Costs for maintaining a hectare in organic versus conventional one reach higher values, up to $20 \%$ (Murfatlar), reaching 35\% (Târnave).

Concerning quantity of harvest obtained, that was lower in organic plots comparative with the control (conventional) with slightly different for varieties Chardonnay and Cabernet Sauvignon (Dealu Mare) and for Fetească regala (CopouIasi). In the Murfatlar vineyard, both varieties Chardonnay and Cabernet Sauvignon recorded lower production values $(-26,24 \%$, respectively 21,55\%).

The average weight of a grapes was higher in organic version at Murfatlar, Dealu Mare and Copou-Iasi, due to green works executed additionally, within these plots (Figure 2). 
Tab. 3. t-Test: Paired Two Sample for Means ecologic (VE) and control (VC) plots - interval 2013-2014

\begin{tabular}{|c|c|c|c|c|c|c|}
\hline \multirow{2}{*}{$\begin{array}{c}\text { Parameters } \\
\text { Variants } \\
\end{array}$} & \multicolumn{2}{|c|}{ Sugar Content g/l } & \multicolumn{2}{|c|}{ Total acidity g/H2SO4 } & \multicolumn{2}{|c|}{ Weight of 100 berries (g) } \\
\hline & $V E$ & $V C$ & $V E$ & $V C$ & $V E$ & $V C$ \\
\hline Mean & 214.5 & 214.3 & 6.345455 & 6.209091 & 159.1455 & 160.1091 \\
\hline Variance & 231.5 & 186.5 & 1.014727 & 1.170909 & 781.0947 & 674.9389 \\
\hline Observations & 11 & 11 & 11 & 11 & 11 & 11 \\
\hline Pearson Correlation & 0.92 & & 0.90 & & 0.97 & \\
\hline $\begin{array}{c}\text { Hypothesized Mean } \\
\text { Difference }\end{array}$ & 0.5 & & 0.5 & & 0.5 & \\
\hline df & 10 & & 10 & & 10 & \\
\hline t Stat & -0.16772 & & -2.5118 & & -0.74287 & \\
\hline $\mathrm{P}(\mathrm{T}<=\mathrm{t})$ one-tail & 0.435075 & & 0.015409 & & 0.237325 & \\
\hline t Critical one-tail & 1.812461 & & 1.812461 & & 1.812461 & \\
\hline $\mathrm{P}(\mathrm{T}<=\mathrm{t})$ two-tail & 0.87015 & & 0.030817 & & 0.47465 & \\
\hline t Critical two-tail & 2.228139 & & 2.228139 & & 2.228139 & \\
\hline
\end{tabular}

Tab. 4. Pearson correlation coefficients - Ecologic (VE) and control (VC) plots - interval 2013-2014.

\begin{tabular}{cccccccc}
\hline Vineyard & Variety & \multicolumn{2}{c}{ Sugar content g/l } & \multicolumn{2}{c}{ Acidity g/H2SO4 } & \multicolumn{2}{c}{ Weight of 100 berries (g) } \\
\hline Murfatlar & Chardonnay & 232.0 & 228.2 & 4.8 & 4.8 & 136.4 & 144.0 \\
\hline & $\begin{array}{c}\text { Cabernet } \\
\text { sauvignon }\end{array}$ & 204.5 & 212.9 & 5.1 & 4.8 & 127.0 & 134.0 \\
\hline Dealu Mare & Chardonnay & 228.0 & 222.0 & 6.9 & 7.0 & 155.0 & 148.0 \\
\hline & $\begin{array}{c}\text { Cabernet } \\
\text { sauvignon }\end{array}$ & 247.0 & 243.0 & 7.1 & 7.8 & 153.0 & 164.8 \\
\hline Tarnave & $\begin{array}{c}\text { Fetească } \\
\text { regala }\end{array}$ & 203.1 & 198.5 & 8.2 & 7.4 & 150.4 & 151.9 \\
\hline & $\begin{array}{c}\text { Muscat } \\
\text { ottonel }\end{array}$ & 216.7 & 215.8 & 7.2 & 7.3 & 176.1 & 176.9 \\
\hline Bujoru & Sauvignon & 209.6 & 219.4 & 6.4 & 6.4 & 107.8 & 106.5 \\
\hline $\begin{array}{c}\text { Feteasca } \\
\text { regala }\end{array}$ & 212.0 & 206.0 & 5.5 & 5.3 & 190.9 & 180.1 \\
\hline Merlot & 205.0 & 200.0 & 6.5 & 5.4 & 174.0 & 178.0 \\
\hline Copou-Iasi & Fetească albă & 206.0 & 213.0 & 6.4 & 6.5 & 184.0 & 182.0 \\
\hline & $\begin{array}{c}\text { Fetească } \\
\text { regală }\end{array}$ & 196.0 & 199.0 & 5.7 & 5.6 & 196.0 & 195.0 \\
\hline average & 214.5 & 214.3 & 6.3 & 6.2 & 159.1 & 160.1 \\
\hline & st. dev. & 15.2 & 13.7 & 1.0 & 1.1 & 27.9 & 26.0 \\
\hline $\begin{array}{c}\text { Pearson } \\
\text { correlation } \\
\text { coefficient }\end{array}$ & & 0.92 & & 0.90 & & 0.97 \\
\hline
\end{tabular}

The sugar content and total acidity of the grapes has values within normal limits in both growing versions, best values have between registered at Cabernet Sauvignon - Dealu Mare, both organic variants as well as the conventional (over $240 \mathrm{~g} / \mathrm{l}$ ), followed by Chardonnay, in the Murfatlar, reached values 232 or $228 \mathrm{~g} / \mathrm{l}$. Values over $200 \mathrm{~g} / \mathrm{l}$ is recorded in almost all varieties 
grown in the five wine regions. Total acidity of the grapes has values within normal limits in both growing versions, registering values between $4,8 \mathrm{~g} / \mathrm{l} \mathrm{H}_{2} \mathrm{SO}_{4}$ at Chardonnay grown in Murfatlar vineyard and 8,2 g/l H2SO4 at Fetească regala from Târnave.

Concerning the weight of 100 grains, the values registered are higher on Chardonnay (Dealu Mare), Feteasca regala (Bujoru and CopouIasi) and Feteasca alba (Copou-Iasi) in ecological variants in comparison with the rest of varieties that have registered higher values in conventional variants.

In statistical terms, it can be seen that there is no statistical difference between means and variances for VE and VC for any of the 3 groups (sugar content, total acidity in must and the weight of 100 berries) (Table 3 ).

Pearson correlation coefficients are 0.9 and above, which it means that values are strongly correlated (strong correlation) (table 4).

Overall, it is observed that culture system (organic versus conventional) does not influence the quality of the grapes, comparing with biodynamic system where are observed higher quality (Reeve et al, 2005), these assuring, in studied conditions, obtain wines with controlled denomination origins (Ranca et al, 2013).

\section{CONCLUSIONS}

In the two years of study, 2013 and 2014, the climatic conditions are normal, without excessive hydric resources. The degree of weeds infestation is relatively high, mainly in Murfatlar, Dealu Mare and Bujoru - over 25\%, which requires additional management measures. The highest diseases attack was registered in Dealu Mare (for all observed diseases), in Murfatlar for oidium and in Bujoru for downy mildew, fact who impose to adapt the treatments scheme for each vineyard.
The study demonstrates that in normal climatic conditions it is possible to adopt and implement with precaution organic culture system of grape-vine in all five vineyards selected.

The comparativeanalysis of quality parameters of harvest: sugar content and total acidity in must, the weight of 100 berries show that there are no differences statistically assured between ecologic growing system and conventional one.

Research must continue in condition of humid years and with other grapes varieties.

Acknowledgments. This work was supported by the Ministry of Agriculture and Rural Development, Research Project ADER 1.1.14.

\section{REFERENCES}

1. Bernaz G, Dejeu L (1999)- Fertilizarea viilor si intretinerea solului in conceptie ecologica.

2. Constantinescu G, Doneaud A, Dragomir E (1964) Stabilirea valorii indicelui bioclimatic al vitei de vie pentru principalele podgorii ale R.P.R., Studii si cercetari de Biologie. Seria Botanica. Tomul XVI (1-14)

3. Ranca A, Toncea I (2011) - Cultura viței-de-vie şi vinificația în sistem ecologic - Total Publishing București, ISBN 978-606-8003-14-6.14.

4. Ranca A, Antoce A, Artem V, Petrescu A, Stanciu C, Colic C (2013) - Principles of organic viticulture applied in Murfatlar vineyard, Romania. IV International Symposium „Agrosym 2013” (743-749).

5. Reeve J, Carpenter-Boggs L, Reganold J, York A, McGrourty G, McCloskey P (2005) - Soil and wine grape quality in biodinamically and organically managed vineyards, American Journal od Enology and Viticulture 56-4 (367376).

6. Teodorescu S, Popa A, Sandu G (1987) Oenoclimatul Romaniei.

7. *** https://shop.fibl.org/fileadmin/documents/ shop/1698-organic-world-2016.pdf

8. *** http://www.infomina.ro/pdf/Despre piata BIO din Ro.pdf

9. *** http://www.madr.ro/agricultura-ecologica/legislatiecomunitara-ae.html 